\title{
Indicator of Zakat over Muzakki An Explanatory Study on BAZNAS of Central Java Province
}

\author{
1.Suraji \\ Postgraduate School \\ Airlangga University \\ Surabaya, Indonesia \\ E-mail: surajistia@gmail.com
}

\author{
2. Sri Iswati \\ Postgraduate School \\ Airlangga University \\ Surabaya, Indonesia \\ E-mail: iswati.fena@gmail.com
}

\begin{abstract}
This research aims to analyse and identify the effect of the perceived service, knowledge and intention of paying zakat (tithe). The problem statement in this research was "what is the effect of perceived service, knowledge and intention on the implementation of zakat payment?' The sample of the research study was obtained through distributing questionnaire to 180 respondents. The variables of the research were perceived service, knowledge, intention, and zakat payment. The variables were elaborated on and sorted into 18 indicators to measure the research instrument using a Likert scale. Analysis was carried out referring to the hypothesis to be tested using SEM. Before the analysis was conducted, validity, reliability and model tests were first conducted on the instrument of the research data. The results of research showed that 1) perceived service positively affects the intention, 2) perceived service positively affects zakat payment, 3) knowledge (science) positively affects intention, 4) knowledge negatively affects the zakat payment, and 5) intention positively affects the zakat payment.
\end{abstract}

Keywords_ intention; knowledge; perceived service; zakat (keywords)

\section{INTRODUCTION}

Government regulations have been released in Law No. 232011 and Government Regulation No. 142014 about zakat, but reality still shows the muzakki's low intention of paying zakat through National Tithe Collector Agency (thereafter called BAZNAS). Central Java is one of areas with substantial potential zakat, but the people's awareness of distributing zakat has not yet increased significantly. Central Java's potential zakat payment is estimated to be about 3.7 billions/year. Meanwhile, in 2013, the zakat revenue accommodated by a number of zakat collector agencies or institutions reaches 1.700 million Rupiah only (Religion Ministry of Central Java Province, 2015).
Fuad Abdul Baqi (2011) stated that zakat is an obligation imposed on every Muslim. It is mentioned 32 times in the Qur'an and repeated 82 times using its synonym, shodaqoh and infaq. Magfirah (2005) confirmed that zakat management should be institutionalised, as zakat is the axis or centre of Islamic state's finance when building the people's economy.

Perceived service is the impression of satisfaction level over a service. The perception intended in this research is muzakki's perception on satisfaction with services in National Zakat Collector Agencies in Regencies/Cities. Parasuraman et al., (1985) and Zeithaml (2011) suggested that in order to measure the service quality, the SERVQUAL (Service Quality) approach can be used. Service quality consists of five determinants: 1) tangibility, 2) reliability, 3) responsiveness, 4) assurance, and 5) empathy. The perceived service variable is measured using the following indicators: 1) tangibility, 2) reliability, 3) responsiveness, 4) assurance, and 5) empathy.

Knowledge relates to cognitive knowledge that can be obtained from the listed sources: the Qur'an, sunnah, ijma, ijtihad, and fatwa. Rofi'i (2015) stated that knowledge is everything brought by the Prophet Muhammad. SAW's best friends (sahabat) include the Qur'an, sunnah, ijma, ijtihad, and fatwa. Knowledge includes: 1) mind, 2) revelation, 3) prophecy and faith and 4) nature (Suryadilaga, 2008). In relation to knowledge, Arikunto (2015) mentioned that the cognitive domain in knowledge has six levels: 1) recognition, 2) comprehension, 3) application, 4) analysis, 5) synthesis and 6) evaluation. In this research study, knowledge is what the muzakki has about zakat.

As-Suyuti's (1403) intention is defined as the impulse to do deeds at the same time. Qardhawi (2001), in the Qur'an, stated that intention is expressed in the form of: "motive wishing hereafter life", "motive of longing for Allah", "wishing Allah", or "wishing Allah's pleasure". The intention variable is measured using the following indicators: 
1) jihad, 2) worship has been kaffah, 3) worship has not been kaffah, 4) worship is mixed with ria (showoff), and 5) humanity worship.

Zakat payments are a condition in which muzakkis comply with all of their zakat payment owed based on Islamic shariah law. There are theories explaining the muzakkis' decision in paying zakat: which is an expected utility theory developed by John von Neumann and Oskar Morgenstern in Kreitener (2010). The zakat payment implementation by muzakki is a series of perceived services, knowledge and the intention to personally and individually be devoted to Allah only. The indicators used to measure the zakat payment implementation variable are: 1) timeliness, 2) data accuracy, and 3) sanction or threat.

\section{METHOD}

\section{A. Method of Collecting Data}

This research employed a primary data source. The sample was taken using proportional area sampling technique taking in the muzakkis existing in seven regencies and three cities in the northern coastal areas of Central Java with 180 respondents in total. The questionnaire distributed contained the statements measured using a Likert scale that would be responded to directly by the respondents. The analysis was carried out referring to the hypothesis using the AMOS version -16 program.

\section{B. Indicators of research variable}

This research used 4 variables and 18 indicators.

TABLE 1.

\begin{tabular}{|c|c|c|c|}
\hline Variables & Indicators (18) & $\begin{array}{l}\text { Number } \\
\text { of Items }\end{array}$ & $\begin{array}{c}\text { Likert Scale } \\
(1-5)\end{array}$ \\
\hline $\begin{array}{l}\text { Perceived } \\
\text { service }\end{array}$ & $\begin{array}{l}\text { tangible } \\
\text { reliability } \\
\text { responsiveness } \\
\text { assurance } \\
\text { empathy =5 }\end{array}$ & $\begin{array}{l}4 \\
5 \\
4 \\
4 \\
5=22 \\
\end{array}$ & $\begin{array}{l}1 \text { - very bad } \\
5 \text { - very } \\
\text { good }\end{array}$ \\
\hline Knowledge & $\begin{array}{l}\text { recognition } \\
\text { comprehension } \\
\text { application } \\
\text { synthesis/analysis } \\
\text { Evaluation = 5 }\end{array}$ & $\begin{array}{l}7 \\
4 \\
6 \\
3 \\
5=25 \\
\end{array}$ & $\begin{array}{l}1 \text { - very low } \\
5 \text { - very } \\
\text { high }\end{array}$ \\
\hline Intention & $\begin{array}{l}\text { jihad } \\
\text { worship has been } \\
\text { kaffah } \\
\text { worship has not been } \\
\text { kaffah } \\
\text { worship with ria } \\
\text { humanity worship = } 5\end{array}$ & $\begin{array}{l}4 \\
5 \\
3 \\
3 \\
4=19 \\
\end{array}$ & $\begin{array}{l}1-\text { very } \\
\text { weak } \\
5-\text { very } \\
\text { strong }\end{array}$ \\
\hline $\begin{array}{l}\text { Zakat } \\
\text { payment }\end{array}$ & $\begin{array}{l}\text { timeliness } \\
\text { data accuracy } \\
\text { sanction }=3\end{array}$ & $\begin{array}{l}7 \\
5 \\
4=16\end{array}$ & $\begin{array}{l}\text { 1-very } \\
\text { disobedient } \\
5 \text { - very } \\
\text { obedient }\end{array}$ \\
\hline
\end{tabular}

\section{Model Framework}

This research studies the causal relationship between variables. The relationship between causality variables has positive direction, meaning that the stronger or the higher the perceived service, knowledge and intention variables, the higher is the zakat payment variable..

\section{FIGURE 1.}

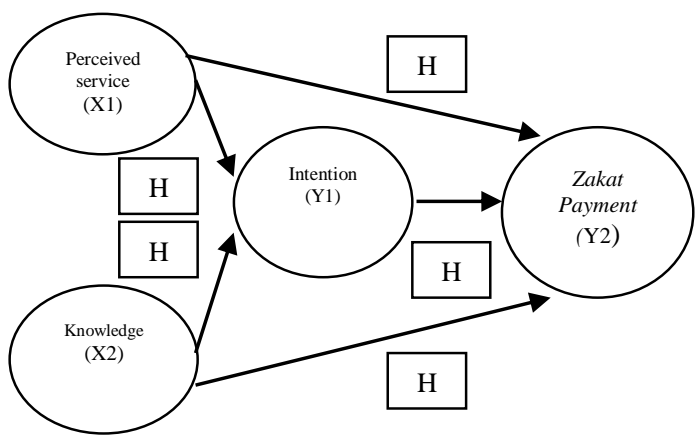

\section{Hypothesis}

Considering the literature study and model framework that has been aforementioned, the hypotheses of the research study has been formulated as follows:

H1. Perceived service positively affects the intention of paying zakat in BAZNAS of Regency/Cities of Central Java Province.

$\mathrm{H} 2$. Knowledge positively affects the intention of paying zakat in the BAZNAS of the Regencies/cities of the Central Java Province.

H3. Service quality affects zakat payment in the National Zakat Collector Agencies in the Regencies and Cities of Central Java Province.

H.4. Knowledge positively affects zakat payment in the BAZNAS of the Regencies and cities of the Central Java Province.

H.5. Intention positively affects zakat payment in the BAZNAS of the Regencies and cities of the Central Java Province.

\section{RESULTAND DISCUSSION}

A. Result

1) Descriptive Analysis

The respondents consist of 180 muzakki distributed within seven regencies and three cities in the northern coastal areas of Central Java. There were $107(54.9 \%)$ males and $73(40.6 \%)$ females. Most (140 or $77.78 \%$ ) muzakkis had college education (postgraduate, graduate and undergraduate), and $40(22.22 \%)$ of them had an education level of Senior High School and below. Most of them (145 or $80.65 \%$ ) were Civil Servants, and $35(19.5 \%)$ had professions other than Civil Servant.

About 162 (90\%) muzakkis admitted to paying zakat in BAZNAS only, and 18 (10\%) admitted to not paying in the zakat collector institution. One hundred and eighteen (65.6\%) muzakkis understood zakat based on the Qur'an Surrah at-Taubah (9) verses 60 and 103, and 62 $(34.4 \%)$ have not understood. One hundred and five 
(58.39\%) muzakkis have understood the Zakat Law Number 23 2011, and 75 (41.61\%) have not understood.

\section{2) Model Test on the Inter-variable Effect}

The evaluation on the goodness-of-fit criteria based on the AMOS program has been presented in Table 2 .

TABLE 2.

\begin{tabular}{|l|l|l|l|}
\hline Criteria & $\begin{array}{l}\text { Model } \\
\text { Result }\end{array}$ & $\begin{array}{l}\text { Critical } \\
\text { Value }\end{array}$ & $\begin{array}{l}\text { Model } \\
\text { Evaluation }\end{array}$ \\
\hline NFI & 0.884 & $\geq 0.90$ & Marginal \\
TLI & 0.914 & $\geq 0.90$ & Fit \\
CFI & 0.928 & $\geq 0.90$ & Fit \\
RMR & 0.028 & $\leq 0.05$ & Fit \\
RMSEA & 0.088 & $\leq 0.08$ & Marginal \\
AGFI & 0.791 & $\geq 0.90$ & Unfit \\
GFI & 0.845 & $\geq 0.90$ & Marginal \\
Cmindf & 2.391 & $\leq 2.0$ & Marginal \\
Probability & 000 & $\geq 0.05$ & Unfit \\
\hline
\end{tabular}

Referring to Solimun (2005), based on parsimony and the rule of thumb principle when there are one or two goodness-of-fit criteria after having fulfilled the fitness criteria, the model is categorised as good. Thus, the goodness-of-fit criteria are acceptable.

\section{3) Hypothesis Test}

The result of SEM analysis with multiple regression using AMOS version-16 program has been presented in Table 3 .

TABLE 3.

\begin{tabular}{|l|l|l|l|l|}
\hline No. & Hypothesis & C.R. & p & Notes \\
\hline 1. & $\begin{array}{l}\text { The effect of } \\
\text { perceived } \\
\text { service on } \\
\text { intention }\end{array}$ & 4.084 & 000 & $\begin{array}{l}\text { Positive } \\
\text { significant }\end{array}$ \\
\hline 2. & $\begin{array}{l}\text { The effect of } \\
\text { knowledge } \\
\text { on intention }\end{array}$ & 2.888 & 0.004 & $\begin{array}{l}\text { Positive } \\
\text { significant }\end{array}$ \\
\hline 3. & $\begin{array}{l}\text { The effect of } \\
\text { perceived } \\
\text { service on } \\
\text { zakat } \\
\text { payment }\end{array}$ & 3.527 & 000 & $\begin{array}{l}\text { Positive } \\
\text { significant }\end{array}$ \\
\hline 4. & $\begin{array}{l}\text { The effect of } \\
\text { knowledge } \\
\text { on zakat } \\
\text { payment }\end{array}$ & -2.722 & 0.006 & $\begin{array}{l}\text { Negative } \\
\text { significant }\end{array}$ \\
\hline 5. & $\begin{array}{l}\text { The effect of } \\
\text { intention on } \\
\text { zakat } \\
\text { payment }\end{array}$ & 5.121 & 000 & $\begin{array}{l}\text { Positive } \\
\text { significant }\end{array}$ \\
\hline
\end{tabular}

\section{B. Discussion}

1). Hypothesis 1 is supported. C.R value $=4.084 ; \mathrm{p}$ $=0.000$; this indicates that the better the service provided, the higher the muzakki's intention of paying zakat in the institution. The results of the study of this supports the research of Ram Al. (2010) Muklis and Irfan (2013).

2). Hypothesis 2 is supported. C.R value $=2.888 ; \mathrm{p}$ $=0.000$; this indicates that there is a positive relationship between knowledge and intention, meaning that the higher the knowledge that exists, the stronger the intention of paying zakat at the zakat institution. The results of this study aligns with the results of Zainol Bidin (2009).

3). Hypothesis 3 is supported. C.R value $=3.527$; $p$ $=0.000$, meaning that the better the service, the higher the zakat payment. The results of this study are in line with the results of Dahlan Thamrin (2010)

4). Hypothesis 4 is not supported. C.R value = 2.722; $\mathrm{p}=0.006$, meaning that there is a negative relationship between knowledge and zakat payment. The results of this study are different to the results of the research conducted by Emmy (2008).

5). Hypothesis 5 is supported. C.R value $=5.121 ; \mathrm{p}$ $=0.000$, indicating that there is a positive effect of intention on zakat payment, meaning that the higher the intention, the higher the zakat payment. The results of this study align with the results of the study done by Sularno (2010).

\section{CONCLUSION}

This study concludes that: 1) Perceived service positively affects the intention of paying zakat. 2). Knowledge positively affects the intention of paying zakat. 3) Service quality positively affects zakat payment. 4) Knowledge negatively affects zakat payment and 5) Intention positively affects zakat payment.

Thus, perceived service and knowledge affects intention and through intention, perceived service affects zakat payment in the BAZNAS of the regencies and cities in the Central Java province.

\section{ACKNOWLEGMENT}

On this occasion, let me gratefully say thanks to the organising committee leader who accepted me as a participant of the International Conference of Post Graduate School of Airlangga University of Surabaya, Indonesia. The director of the Post Graduate School of Airlangga University of Surabaya, Indonesia along with the staff who informed me about the International Conference held on the $1^{\text {st }}$ to $2^{\text {nd }}$ August 2017, so that I could attend the conference, are also to be thanked. The head of the School of Administrative Sciences who allowed me to attend the conference has my deepest gratitude, as does the Chairman of the BAZNAZ of the Central Java province who has been given the recommendations. And lastly, my thanks go to the Chairman of the BAZNAZ district and municipalities in Central Java who has given me the chance to conduct research in the region. 


\section{REFERENCES}

ArikuntoSuharsimi,

Dasar-

DasarEvaluasiPendidikan,

PenerbitBumiAksara, Jakarta, 2015, pp. 134

As-Suyuti, al - Ashabahwa-al-Nadh'ir, Dar alKutub al-Ilmiyah, Beirut, 1403H, pp. 33

Dahlan Thamrin, Faktor-Faktor yang Mempengaruhi Muzakki menunaikan Zakat pada Baitul Mal masjid Jami An-Nur,e jurnal . Direktorat P2M Dikti Depdiknas bekerjasama dengan PDII-LIPI PSTT-PPs UI, 2010.

Ekonomi Islam La-Riba Vol.IV Juli 2010. Pp.15-26

Emmy, Analisis Faktor yang mempengaruhi pengumpulan ZIS, Wakaf dan Qurban,pada Badan Pengelola Zakat,, Jurnal EKIS, PSTT PPs-UI,Vol.4 Jan-Maret 2008.

Fuad Abdul Baqi, Dalil-DalildanKeutamaan Zakat, Infaq, Shadaqah,Penerbit PT. Elex Media Komputindo.S, Jakarta, 2011, pp.134

Kementerian Agama PropinsiJawa Tengah, 2015, Data BAZNAS kabupatendankotaTahun 2011-2015, Semarang, 2016.

Magfirah, "UrgensiKewajiban Zakat dalam Islam", JurnalHukumIslam, Volume IV, No.2, Desember 2005, UII Yogyakarta, 2005, pp. 203

Muklis, Irfan, Analisis Faktor-Faktor yang Mempengaruhi Tingkat Kepatuhan Membayar Zakat: Studi kasus di kabupaten Bogor, Jurnal al-Muzara'ah, Vol 1, 2013.

Parasuraman, A., Zeithaml, W. And Berry, " $A$ conceptual model ofservice quality and its implications for future reseach", Journal of Marketing, Vol 49, 1985, pp. 41-50.

PeraturanPemerintahRepublik Indonesia $\begin{array}{llll}\text { Nomor } & 14 & \text { Tahun } & 2014\end{array}$ TentangPelaksanaanUndang-

Plous Scott,The Psychology of Jugment and Decision Making, USA : McGtaw-Hill, 1995, pp. 80-82
Qardhawi, Yusuf. Hukum Zakat, (StudiKomparatifMengenai Status danFilsafat Zakat Berdasarkan Qur'an danHadits), Jakarta, PT. PustakaLiteraAntarnusa, Jakarta, 2001, pp. 11

Ram Al, Faktor-Faktor yang Mempengaruhi Gelagat Kepatuhan Zakat Perniagaan, Jurnal Pengurusan Edisi 30 Juli 2010.

Rofi'i,Tholabul 'Ilmi, TraskripCeramah AQI 190207, 2015, pp.3

Solimun, Structural Equation Modeling (SEM), Aplikasi Software AMOS, FakultasMIPA dan Program PascasarjanaUniversitasBrawijaya Malang,2005, pp. 55

Sularno, Pengelolaan Zakat oleh BASDA Kabupaten/Kota di DIY, Jurnal

SuryadilagaAlfatih Muhammad, HadisHadisTentangIlmuDalamKitab Al-KafiKarya AlKulaini, Yogyakarta, Disertasi . Program Pascasarjana UIN SunanKalijaga, 2008, pp. 158203

Undang-UndangRepublik Indonesia Nomor 23 Tahun 2011 TentangPengelolaan Zakat. Kementerian Agama Kantor Surakarta Tahun 2012.

UndangNomor $28 \quad$ Tahun 2011 TentangPengelolaan Zakat, SalinanPrisidenRepublik Indonesia, Jakarta, 2015.

Zainol Bidin, Predicting Compliance Intention on Zakah on Employment Income in Malaysia: An Application of Research action Theory, IKAZ, International Journal of Zakah, Vol 28, 2009.

Zeithaml, Consumer erception of Price, Quality and Value, Journal of Marketing, Vol.52, 2011, UNDIP pp. 30-39 